\title{
Geoconservation as an Emerging Geoscience
}

\author{
Maria Helena Henriques • Rui Pena dos Reis • \\ José Brilha $\cdot$ Teresa Mota
}

Received: 18 October 2010 /Accepted: 5 April 2011 /Published online: 21 April 2011

(C) Springer-Verlag 2011

\begin{abstract}
The main purpose of geoconservation is the conservation of geosites as basic units of the geological heritage through the implementation of specific inventory, evaluation, conservation, valuation and monitoring procedures. In this paper, geoconservation is characterised as an emergent geoscience within the Earth and Space Sciences where its scope and methods, as well as production and validation of knowledge can be recognised-thus defining Basic Geoconservation-, interrelations with other earth sciences can be established-thus supporting Applied Geoconservation-, and Technical Applications of Geoconservation can be identified through the production of materials, methods and/or scientific services useful to society, namely
\end{abstract}

M. H. Henriques $(\square)$

Earth Sciences Department,

Group of Sedimentary Geology and Fossil Record,

Geosciences Centre, University of Coimbra,

Largo Marquês de Pombal,

3000-272 Coimbra, Portugal

e-mail: hhenriq@dct.uc.pt

\section{R. P. dos Reis}

Faculty of Sciences and Technology, University of Coimbra, Largo Marquês de Pombal,

3000-272 Coimbra, Portugal

e-mail: penareis@dct.uc.pt

\section{J. Brilha}

Geology Centre of the University of Porto and Earth Sciences

Department of the University of Minho,

Braga, Portugal

e-mail: jbrilha@dct.uminho.pt

\section{T. Mota}

History of Science and Technology Inter-University Centre,

Museum of Science of the University of Lisbon,

Lisbon, Portugal

e-mail: salome.teresa@gmail.com geoeducation. Promoting scientific education relevant to sustainable development requires new educational approaches involving the Earth Sciences, namely through geoconservation, in order to provide citizens with tools to face environmental problems, such as those arising from the depletion of geological resources - which seriously threaten the geological heritage of the Earth - and the information, skills and will make forward-looking choices, like supporting the legal protection of Natural Monuments and/or the implementation of geotourism (including geoparks).

Keywords Basic Geoconservation · Applied Geoconservation - Technical Applications of Geoconservation - Education for sustainable development

\section{Introduction}

The lifestyle in general of citizens from industrialised countries is based on high rates of consumption of resources, including energy, materials and land, as well as on the increasing production of waste and emissions. Of the environmental impacts associated with this reality, there stands out the deep transformation of the land surface. In Europe, $47 \%$ of the continent is used for agriculture, $36 \%$ is occupied by forest and $17 \%$ has other purposes, including settlements and infrastructure, resulting in significant changes to the basic natural functions of the solid surface of the Earth (EEA 2005) and inevitable destruction of its geological heritage (Gray 2004). If in the next 50 years, the growing population of the developing countries reaches a living standard comparable with those in industrialised countries, it is admitted that the resources consumption will increase two- to fivefold (EEA 2005). This hypothetical scenario 
supports current ideas according to which "We move more material around the Earth's surface than all natural agents of erosion" (Leenaers and Schalke 2004, p. 4). In addition, non-renewable geological resources of cultural nature (the geological heritage of the Earth defined as "cultural georesources" cf. Elízaga Muñoz 1988), the conservation for future generations of which is everyone's responsibility, imposes new challenges for all sectors of society (politicians, businessmen, educators, media), including the geoscientists, as their activity is focused on the production and use of geoscience knowledge.

Two major attitudes arise from the previous two statements:

- On one hand, it is urgent to improve the methods of exploration of geological resources enabling and promoting their sustainable use. Such a task is assigned to geoscientists, who have the responsibility-in collaboration with other professionals - of conceiving and implementing more efficient technologies and instruments for resource exploitation (Sinding-Larsen et al. 2006; Henriques 2008).

- On the other hand, radical changes in citizen's unsustainable consumption rates are required in order to mitigate current problems affecting society, namely those emerging from the fragility of the physical environment. As pointed out by UNESCO (2005a), education is one of the most effective forces to bring about the changes in knowledge, values, behaviour and lifestyles required to achieve sustainability and stability within and among countries, and to guarantee human security, peace and democracy. Such a vision supports the DESD-United Nations Decade of Education for Sustainable Development (2005-2014), which aims for the promotion of an education based on values and raising the respect for others, for diversity, for the environment and for the resources of the planet we inhabit, as the basic value for a participative citizenship (UNESCO 2006).

Geoconservation is related to this new social responsibility towards the use of Earth resources. In spite of this general approach, geoconservation is more focused on the management of those geological elements with exceptional scientific, educational, touristic or cultural value - the geological heritage represented by geosites. In this work, geoconservation is characterised as an emerging geoscience within Earth and Space Sciences, where scientific knowledge is submitted to current validation procedures as in other geosciences. The scope and methods of geoconservation are described, as well as the knowledge, problems, materials, instruments and/or services that make up its different dimensions: Basic Geoconservation, Applied Geoconservation and Technical Applications of Geoconservation.

\section{The Emergence of a New Scientific Domain}

In modern science, the growth of knowledge has been shown to be exponential, in great part, due to the creation of new scientific disciplines or areas of specialisation. The emergence of new scientific areas is thus seen as a central issue in historical and sociological studies of science.

The process of establishment of a given scientific discipline or area of specialisation is a complex one, and historical literature has shown that it is intrinsically related to professionalisation in science, a subject which has been addressed by several authors (Crosland 1975; Morrell and Thackray 1981; Geison 1984; Morrell 1990). Morrell (1990) has given a particularly comprehensive overview on the subject and, even if the model of professionalisation he proposes should not be applied in a too strict way and should take into account special circumstances of time and place, "it provides, nevertheless, useful guidelines and has an inherent heuristic potential" (Carneiro and Leitão 2009, p. 279).

The main factors that characterise professionalisation in science are also present in the establishment of new scientific disciplines: the increase in the number of fulltime paid positions and assured career structures; the establishment of specialist qualifications, for instance, $\mathrm{PhDs}$, which act as a social certification of scientific competence; the implementation of training procedures associated with the emergence of research schools; the growth of specialisation in the development of an esoteric technical language; a growing sense of self-consciousness among practitioners, with the establishment of scientific and professional associations and publications; and the establishment of reward systems intended to recognise the best practice and practitioners.

Historians of science consider particularly relevant the establishment of scientific societies and research schools in the context of scientific specialisation (Morrell 1972; Holton 1978; Fruton 1988; Geison 1993; Servos 1993). In his well-known model concerning research schools, Geison (1981, p. 34) considers that "specialities find their concrete embodiment" in "innovative research schools within traditional disciplines". In research schools, new practitioners are trained by a charismatic and competent leader who possesses a clearly defined research programme, institutional power and funding, usually in an academic context, and with access/control of specialised journals. The leader promotes social cohesion and esprit de corps among the members of the research school and manages to find them suitable paid positions after they leave.

When considering the role of research schools, the emergence of new scientific specialities is seen as intrinsically related to conceptual growth within an already existing scientific discipline or as the result of what Kuhn has named "normal science" (Kuhn 1962). Kuhn was a 
major influence in sociological studies of science, and it is in this context that another model concerning the emergence and establishment of new scientific specialities will be next mentioned.

Mulkay et al. (1975) considered that the establishment of a new scientific area is closely related to the formation of a research network, and the process appears to typically present three stages - exploration, unification, and decline/ displacement - each one of them characterised by a number of associated intellectual and social developments. It is during stage 2 that the most relevant factors concerning the establishment of a new scientific area become stabilised, such as the setting up of an intellectual framework and of cognitive and technical standards; the formation of research groups; the settlement of mechanisms of recruitment and funding; the creation of specialised journals; the recognition of a small number of contributors recognised as "paradigmatic" and who are frequently cited; growth in the amount of research activity in the new area and in the number of its practitioners.

The models here presented must be understood as a background against which each particular case must be considered and analysed. Factors such as a particular social, cultural and/or economic context, public demand and scientific opportunity must also be taken into account, as argued by several authors when considering the emergence of geology in Britain (Porter 1973; Laudan 1990; Knell 2000; Torrens 2002).

\section{Geoconservation as a Geoscience}

The first example of geosite protection dates back to 1668 , concerning the protection of a cave in the Harz Mountains in Germany (Grube 1994). During the nineteenth century, Germany continued to protect geosites and some other countries (such as Denmark, Switzerland, Belgium, Czech Republic) began the protection of certain localities, mainly for their striking geomorphological features. In Britain, the Lepidodendron stumps of "Fossil Grove" in Glasgow have been conserved since its discovery in 1887; at about the same time, the "Agassiz Rock" has been preserved in Edinburgh (Black 1988). Conservation of sites by means of a scientific-based methodology dates back to 1977, when the Geological Conservation Review was established by the Nature Conservancy in Britain (Wimbledon 1988). The first international meeting on geoconservation was held in The Netherlands in 1988, with the presence of seven European countries. One of the outputs of this meeting was the establishment of the European Working Group on EarthScience Conservation (Black and Gonggrijp 1990), which evolved in 1993 to ProGEO-The European Association for the Conservation of the Geological Heritage. Nevertheless, two previous important meetings were held in Britain: the "Geological site conservation in Great Britain" in 1979 (Clements 1984) and "The use and conservation of palaeontological sites" in 1987 (Crowther and Wimbledon 1988), both organised by the Geological Society (London), thus assigning to this country, from the historical point of view, the leadership of the geoconservation movement seeking at scientific basis. It was only by the end of the twentieth century that geoconservation was finally assumed at an international scale by the occasion of the "First International Symposium on the Conservation of our Geological Heritage", held in Digne (France) in 1991 and attended by over 100 specialists from more than 30 nations (DD 1991). In 1993, the Malvern Conference on Geological and Landscape Conservation was another major international scientific event, convened by the Joint Nature Conservation Committee in association with the Geological Society of London and the Geologists' Association (O'Halloran et al. 1994). However, the geoconservation settlement as a body of scientific knowledge records decisive steps over the last two decades, with the establishment of specific organisations aiming "at the structured preservation of earth-scientifically interesting or valuable sites" (Van Loon 2008, p. 252). ProGEO is an example of this kind of society aiming "to organise and participate in research into all aspects of planning, science, management and interpretation that are relevant to geoconservation" (ProGEO 2010).

\section{Scope and Methods}

The scope of geoconservation is the conservation of geosites, as basic units of the geological heritage of the Earth (Henriques 2010), by means of specific inventory, evaluation, conservation, valuing and monitoring procedures (Brilha 2005). A geosite is a place on the Earth's surface which represents "truly significant processes and events, time periods, features and topics" (Wimbledon 1998 , p. 16) of the planet's identity. It can be recognised through the application of the singularity principle, i.e. a place becomes a geosite due to some specific property it detains, acknowledged and valued by experts, and which is singular and therefore relevant for the understanding of the Earth's history and dynamics. Singularity as a global concept assigned to the geological heritage was firstly pointed in the eighth item of "Digne Declaration" (DD 1991), which states: "Man and the Earth share a common heritage, of which we and our governments are but the custodians. Each and every human-being should understand that the slightest damage could lead to irreversible losses for the future. In undertaking any form of development, we should respect the singularity of this heritage".

Different methodologies (designated so far as "strategies") have been developed in geoconservation. Their 
differences result on the use of methods and techniques of inventory, evaluation (using qualitative and/or quantitative systems of classification), conservation (using relevant legal instruments of protection and physical actions), valuation (using appropriate diffusion and educational techniques) and monitoring (periodic or non-periodic) based on different approaches, leading to a great variety of legal regulations and consequent irregular protection of the geological heritage (Carreras and Druguet 1998; Pena dos Reis and Henriques 2009).

Inventory and evaluation procedures play a decisive role on the implementation of subsequent conservation, valuing and monitoring of the geological heritage. These procedures correspond to the "Basic Geoconservation" (like Basic Palaeontology sensu Fernández-López 1988, 2000; Fig. 1). Some inventory and evaluation approaches have considered the selection of geosites based on criteria like abundance-rarity, representativeness, integrity and others, in articulation with further ones based on their use or their vulnerability (e.g. Elízaga Muñoz 1988; Elízaga et al. 1994; Wimbledon 1996; Uceda 2000; Reynard and Panizza 2005; Lima et al 2010; Pereira and Pereira 2010).
As an attempt to reduce subjectivity that is always involved in any selection or assessment but mainly when large territories are being characterised, other approaches defend inventory and evaluation procedures based on the selection of sites in a chosen geological context or framework. This selection is carried out in a comparative and thematic way always supported by scientific data (Wimbledon 1998; Wimbledon et al. 2000a, 2000b; García-Cortés et al. 2001; Satkunas et al. 2004; Theodossiou-Drandaki et al. 2004; Brilha et al. 2005). Taking into account the socio-cultural dimension involved in the characterization of the geological heritage, Henriques (2004) and Pena dos Reis and Henriques (2009) proposed a categorization system for geological heritage based on values or contents integrating both the meaning attributed to the objects by scientific communities (defined as "relevance grade") and the public understanding of such meanings related to the social use of the objects (defined as "abstract perceptiveness").

This body of knowledge, made of specific concepts, principles and methodologies of geoconservation, represents the substantive meaning of geoconservation as a science (sensu Santos 2004; Henriques 2010), where three levels of

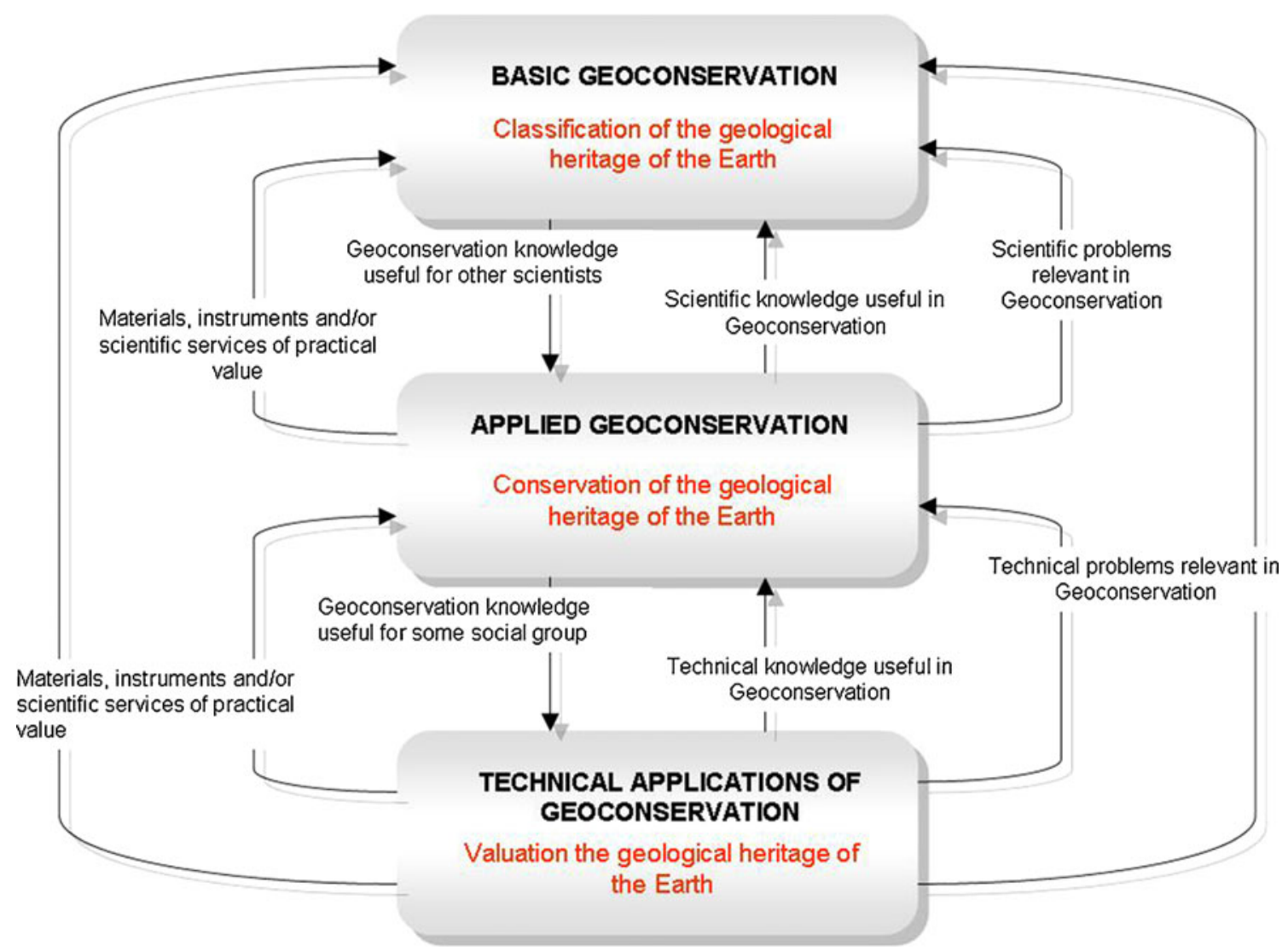

Fig. 1 Flow chart representing knowledge, problems, materials, instruments and/or services between Basic Geoconservation, Applied Geoconservation and Technical Applications of Geoconservation (adapted from original flow chart conceived for Palaeontology by Fernández López 1988, 2000) 
meaning-physical, conceptual and linguistic-and corresponding components can be found (Fernández-López 2000; Fig. 2). Substantive knowledge on geoconservation is useful for other scientists, namely for palaeontologists or mineralogists when palaeontological heritage or mineralogical heritage needs conservation, thus defining the other dimension of this science - the Applied Geoconservation (Fig. 1). Technical Applications of Geoconservation refers to materials, instruments (e.g. laws) and/or scientific services of practical value provided by geoconservation, aimed at valuing geological heritage, through the elaboration and implementation of protection categories assigned to nature conservation or expressing land-use planning policies (e.g. Natural Parks), relevant materials for geoeducation (e.g. field guidebooks) and special services with social impact (e.g. geotourism).

Production and Validation of Knowledge

Production and validation of knowledge in geoconservation, as in other sciences, represent a collective endeavour, highly dependent on social contexts. It includes conventional (but not arbitrary) dimensions and records systematic (but not linear) upgrades (Henriques 2006, 2010). It is based on the existence of a set of procedures governed by rules and institutions involving the presentation and discussion of knowledge in specific forums (Table 1) universities, where expertise in this area of knowledge is recognised and certified and where specialised scientific meetings are organised (Pereira et al. 2008); and its dissemination, after peer reviewing, in recognised scientific publications-books and journals, like Geoheritage, a journal aiming to cover "all aspects of geoheritage and its protection" (Brilha and Wimbledon 2010). The International Geological Congress - the most representative scientific event of the international geological community — has had a thematic session about Geoconservation since its 30th session held in Beijing in 1996, organised by UNESCO and ProGEO. Starting with Digne, ProGEO has organised international symposia, besides the organisation of more local meetings under the leadership of regional workinggroups. Presently, many national geological congresses also organise thematic sessions on Geoconservation, not to mention the large number of meetings that are happening all over the world under this theme.

All these aspects referring to the universe of institutions and procedures involved in the production and validation of knowledge in geoconservation play a decisive role on its settlement as a geoscience (Henriques 2010).

\section{Scientific Framework of Geoconservation}

According to UNESCO's International Standard Nomenclature for Fields of Science and Technology (UNESCO 1988) and despite the need of updating categories as emerging disciplines and subdisciplines become established (Martínez-Frías and Hochberg 2007), Geoconservation should be classified within the Earth and Space Sciences (Code 25), where Geography (code 2505) and Geology (2506) are placed, although Geography, in the same classification, has been also considered as an independent field of knowledge (Code 54). Applied Geoconservation (like Applied Palaeontology sensu Fernández López 1988, 2000; Fig. 1), which aims at the conservation of the geological heritage, provides relevant knowledge for/integrates relevant meaning of other scientific disciplines, namely Geography (Code 2505) - specifically in Geography of Natural Resources (Code 2505.03) and Land Utilization (Code 2505.04 or 5401.03) - and Geology (Code 2506) - namely in Environmental Geology (Code 2505.04) and Geological Surveys (Code 2506.06).
Fig. 2 The three levels of entities and corresponding components distinguishable in any science. The meaning of any term depends on its designation and reference (Fernández López 2000)

\section{Conceptual level}

Concepts, proposals, hypotesis, theories, ...

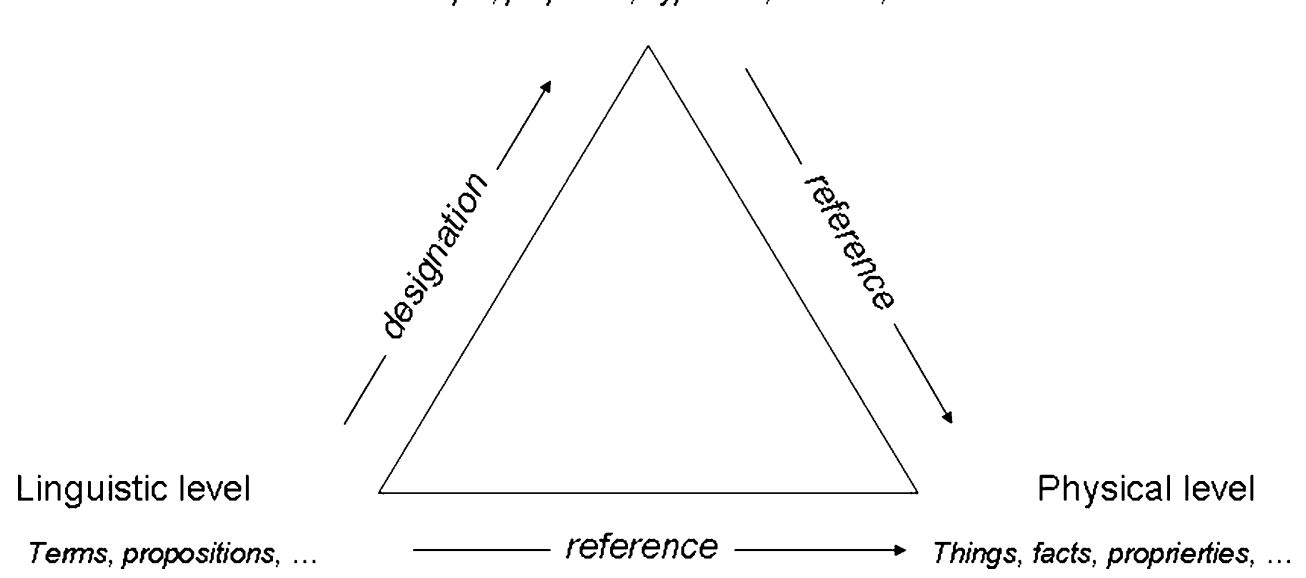

Linguistic level

Tems, propositions, ... 
Table 1 International organisations (beside universities) developing current activities where scientific knowledge in geoconservation can be validated and regularly published

\begin{tabular}{ll}
\hline Organisation & Validation and publication activities \\
\hline The European Association for the Conservation of the Geological Heritage (ProGEO) & $\begin{array}{l}\text { Journal "Geoheritage" } \\
\text { International Symposia } \\
\text { The International Union of Geological Sciences (IUGS) }\end{array}$ \\
$\begin{array}{ll}\text { Journal "Episodes" } \\
\text { The International Geological Congresses }\end{array}$ \\
The Global Geoparks Networks (assisted by UNESCO) & Rivista Italiana di Paleontologia I Stratigrafia \\
International Association of Geomorphologists (IAG) & Geoconservation Working Group \\
\end{tabular}

\section{Social Relevance of Geoconservation}

Geoconservation uses and produces specific knowledge of technical nature allowing the establishment of strong links with the society. Several main connections can be drawn involving Technical Applications of Geoconservation (Fig. 1):

Scientific Research The conservation of geosites with high scientific value is a guarantee that future research, using new tools and techniques, will be conducted by new generations of geoscientists. In many countries, key locations to understand geological phenomena with national and international relevance have been lost due to the absence of any geoconservation strategy. On the other hand, the selection and assessment of geosites must be well founded on science-based data, decreasing the subjectivity associated with any evaluation procedure.

Nature Conservation and Land-Use Planning The assessment of the exceptional value of geological occurrencesone of the aims of geoconservation-determines which geosites should be subjected to protection measures, and thus worthy of resources. These geosites, being notable representatives of natural heritage, must be protected by nature conservation and land-use planning policies (Brilha 2002). This is the reason why geoconservation must be well-supported by adequate legislation, where geology (inanimate) and animate nature are treated equally, where conservation is concerned.

Education When geosites illustrate geological aspects of use in the educational system (from elementary/primary schools to universities), together with a good quality of the exposure and easy accessibility, they turn out to be an excellent educational resource. Formal and informal geoeducation can only be promoted to any significant extent if there is proper Geoconservation action-plan to identify, protect and manage geosites with a high educational value.
The high relevance of the protection of these geosites for education will be stressed in item 4 .

Geotourism The valuation of geosites with a high aesthetic significance contributes to the implementation of geotouristic activities (Hose 2008). When these activities are the background of a sustainable development strategy of a well-defined territory, UNESCO may recognise the territory with the geopark label (Eder 1999; Eder and Patzak 2004). The social fruition of the geological heritage is mainly achieved in national parks and similar structures (natural parks, natural monuments, natural reserves, depending on the legal framework) where it is supported through informative and interpretative actions, namely interpretative panels, brochures, leaflets, field guidebooks, Websites, museums and interpretative centres (Figs. 3 and 4). Many experiences, mostly in geoparks, have shown that geotourism has stimulated creative skills in some of their active agents (restaurants, for instance), who develop tourist products related to the local geological heritage (Fig. 5).

As geoconservation plays an important role in science, education and geotourism, the most relevant geosites, selected according to quantitative assessment methods and being notable representatives of natural heritage, must be protected by nature conservation and land-use planning policies.

\section{Geoconservation and the Education for Sustainable Development}

With the increase in world population and the consequent growing demand for natural resources, it is expected that the maintenance of the integrity of geological objects with heritage value will be more difficult to implement and justify in the near future. The political authorities will be increasingly confronted with the need to mediate such conflicts - to manage a delicate balance between economic 
Fig. 3 Interpretative panels in geoparks of the Global Geoparks Network. a Vulkaneifel Geopark (Germany); b Lesvos Petrified Forest Geopark (Greece)
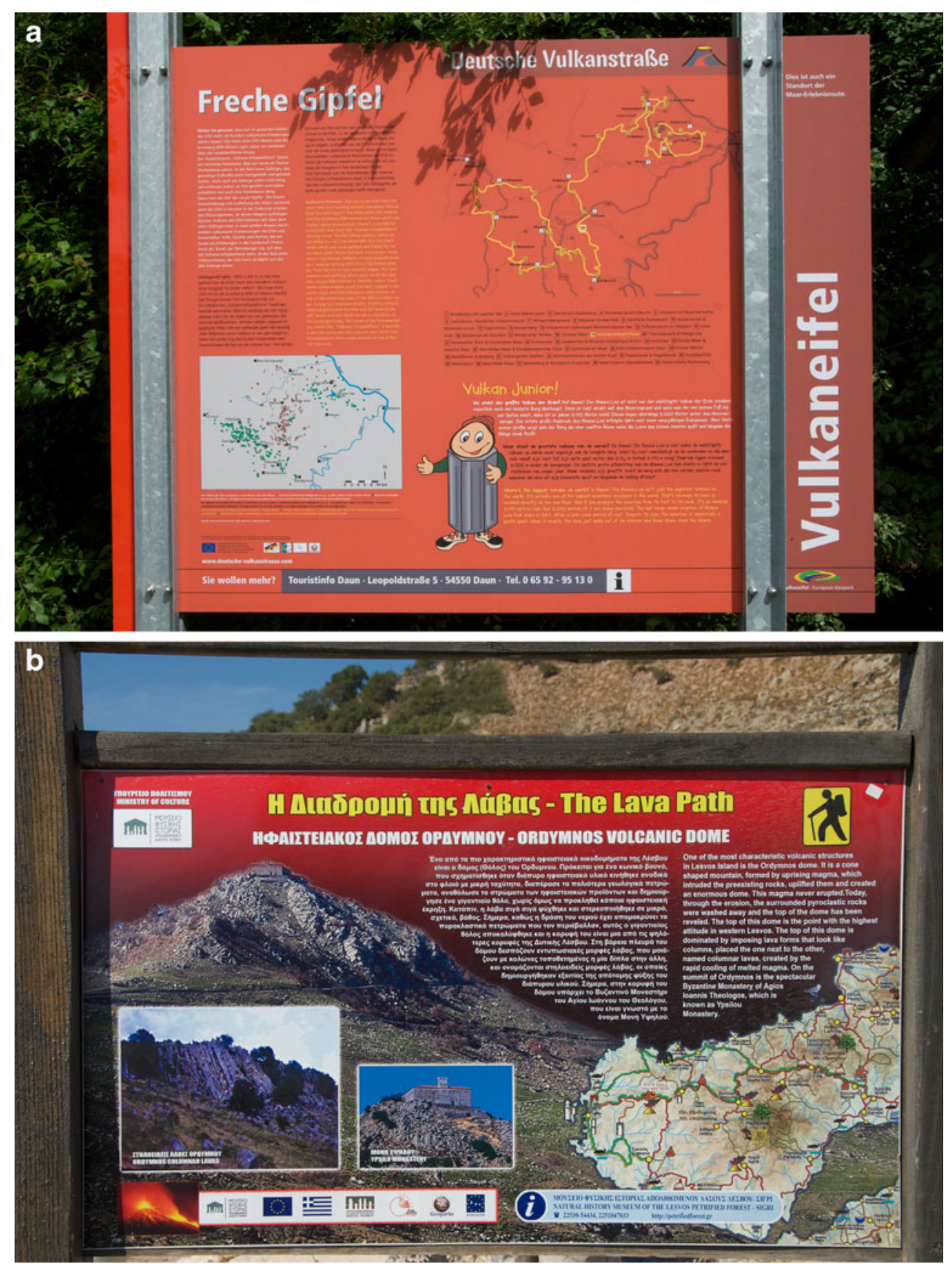

interests and social responsibilities - and to make accountable and science-based decisions on the sustainable use of natural resources. Aiming at such goals, they need to mobilise and use scientific knowledge about the planet, including knowledge on Earth Sciences.

Educational agents at all levels, including those affiliated to higher education institutions - "training [scenario] of political leaders and of senior managers and directors of different public and private institutions and agencies" (Pedrosa and Moreno 2007, p. 17) — are thus required to incorporate into their teaching practices, aspects that promote respect for the evidence that demonstrates the Earth's history. Such a main concern of geoconservation is totally consistent with the perspectives that underlie the vision and definition of education for sustainable development, as pointed out by UNESCO for the 2005-2014 DESD (UNESCO 2005b). To promote it, deep reorientation of the educational programmes is required, at all levels, including universities, so as to integrate a clear focus on the development of knowledge, skills (critical and creative thinking, communication, conflict management and problem-solving strategies, project assessment), perspec- 
Fig. 4 Interactive installation at Alto Tajo Natural Park (Spain)

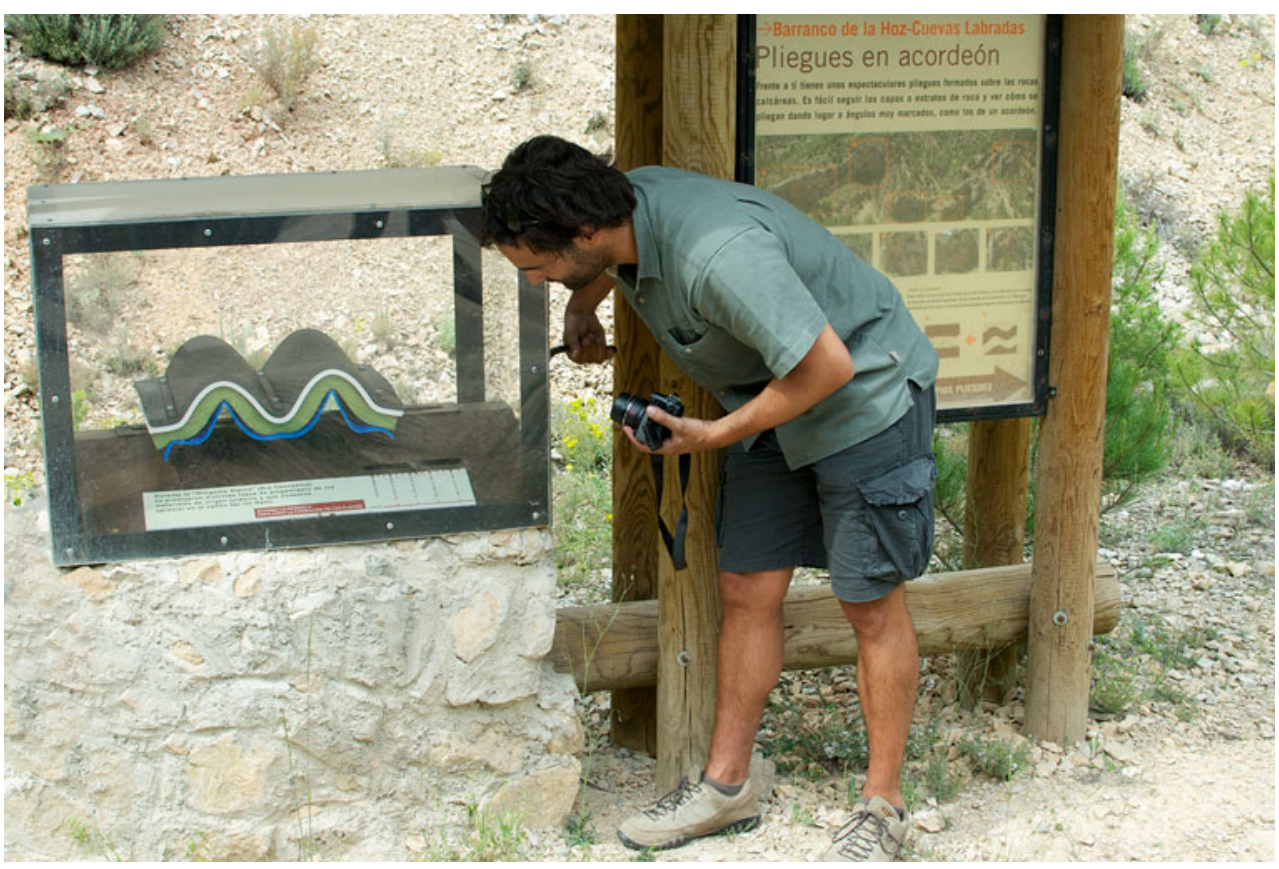

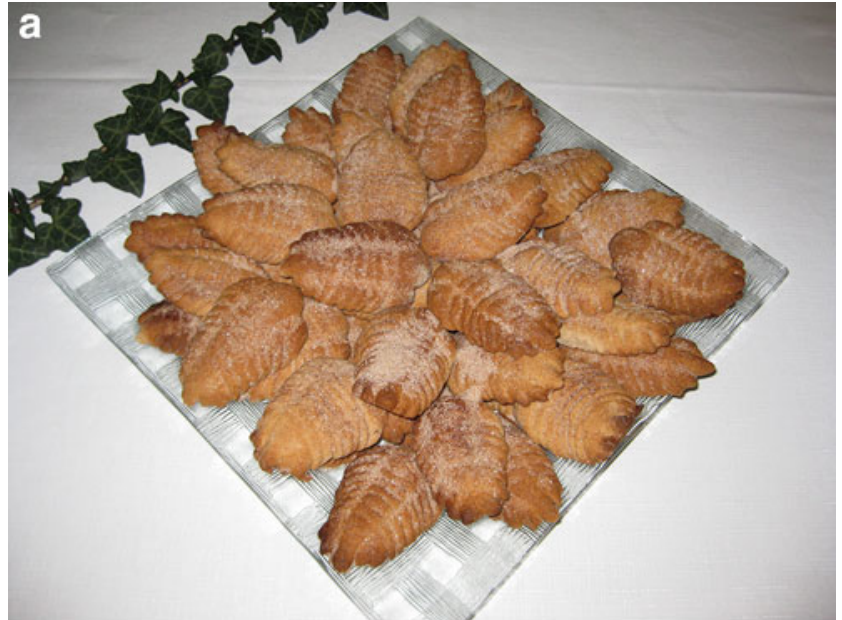

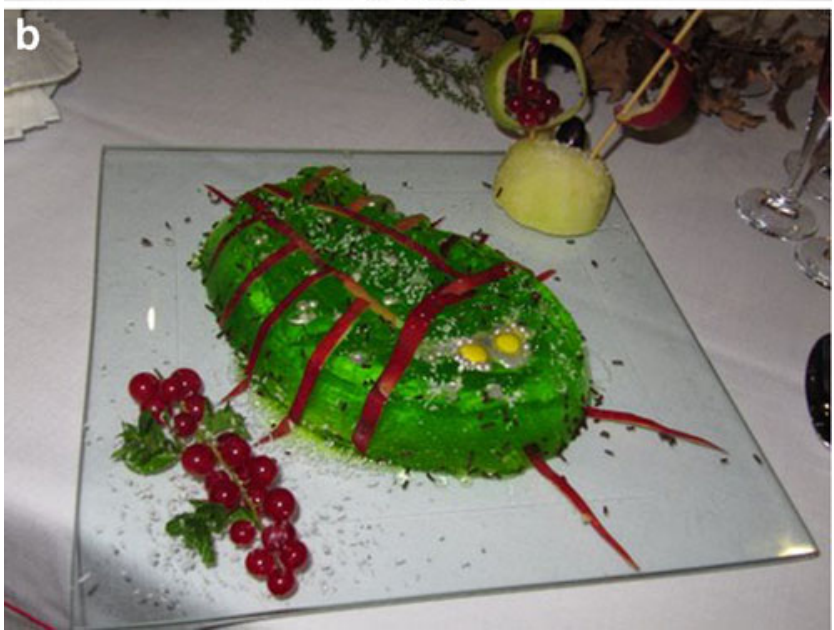

Fig. 5 Special recipes of Arouca Geopark (Portugal): a Trilobite cookies; b Trilobite jelly tives and values related to sustainability, "enabling citizens to face the challenges of the present and future, and leaders to make relevant decisions for a viable world" (...) and "to take an active part in and contribute to the life of society, be respectful of the Earth and life in all its diversity" (UNESCO, op. cit., p. 4). It requires the design and implementation of educational interventions: to mobilise knowledge of the Earth Sciences, geoconservation included, addressing present and future issues and concerns of citizen's life, which can stimulate them to adopt sustainable lifestyles and to exercise active and responsible citizenship (Pedrosa and Moreno 2007).

Bringing the Earth Sciences to all citizens, emphasising its potential in building a safe, healthy and prosperous society, was precisely the central aim of the International Year of Planet Earth, during the triennium 2007-2009 (De Mulder et al. 2006). The initiative sought to reveal the role of science education, particularly in Earth Sciences, in training citizens committed to sustainability of the planet and its resources, and highlighted the value of geoparks as instruments of public conservation and development (Eder and Mulder 2008; Henriques et al. 2010).

Geoconservation, as an emerging discipline within the Earth Sciences, produces useful knowledge to solve environmental problems of social relevance, like those resulting from the over-exploration of geological resources or improper land-use planning, which may endanger the physical integrity of geoheritage. In addition, it designs suitable and specialised services necessary and relevant for their mitigation. It thus defines a body of knowledge of crucial importance in the creation of 
products (e.g. interpretative trails, reserves, geoparks) which, in addition to guaranteeing the protection of nature, are capable of promoting economic and social development at every scale from local to global (e.g. through geotourism) reaching out to current interpretations of sustainable development.

Geosites, as elements of the geological heritage of the Earth, the subject of study in geoconservation, represent important educational resources. These resources may enhance learning opportunities, integrating the three interactive teaching meanings of geoconservation as a geoscience (sensu Santos 2004; Henriques 2008, 2010; Fig. 6):

- Education on geoconservation, or the substantive knowledge developed by geonconservation, i.e. Basic and Applied Geoconservation;

- Education about geoconservation, or its metaphysical dimension, in the philosophical sense of the concept, i.e. the knowledge referring to the universe of institutions and procedures involved in the production and validation of knowledge in geoconservation;

- Education through geoconservation, or the knowledge specifically directed for the training of responsible and active citizens, enabling them to participate in discussions about environmental problems - which threatens geological heritage - and to make responsible decisions that are aimed at mitigating such problems. As an example, the creation of geoparks or the protection of natural monuments deeply depends on citizens' involvement (Gray and Gordon 2008).

\section{Final Remarks}

Whatever the model considered for explaining the emergence of scientific disciplines or new areas of scientific specialisation, it is possible to recognise some common transversing elements among them: an appropriate institutional context which allows for the recruitment of new practitioners and funding, the creation of research schools, and increasing specialisation manifested in specific academic qualifications, journals and scientific societies. All these elements seem to be present in the case of geoconservation. Furthermore, writing about the issue-something that the authors of this paper are doing - is also another (historical) way of legitimising a scientific discipline, of establishing an epistemological and methodological framework in which the practices adopted can be sanctioned as acceptable science and of demarcating and redefining discipline boundaries (Laudan 1983).

Despite the historically persistent resistance of academics to new scientific paradigms, the contemporary major issues related to environmental problems of social relevance have led to the presently occurring change of a group of people interested in Geoconservation into a professional one, as well as to the recognition of Geoconservation as a new body of scientific knowledge, integrating a disciplinary group.

In geoconservation, it is possible to differentiate several purposes relating to geoheritage: inventory and evaluation (defining the Basic Geoconservation), and conservation (defining the Applied Geoconservation) and valuation (defining the Technical Applications of Geoconservation;
Fig. 6 The three interactive teaching universes of geoconservation as a geoscience (sensu Santos 2004; Henriques 2008, 2010)

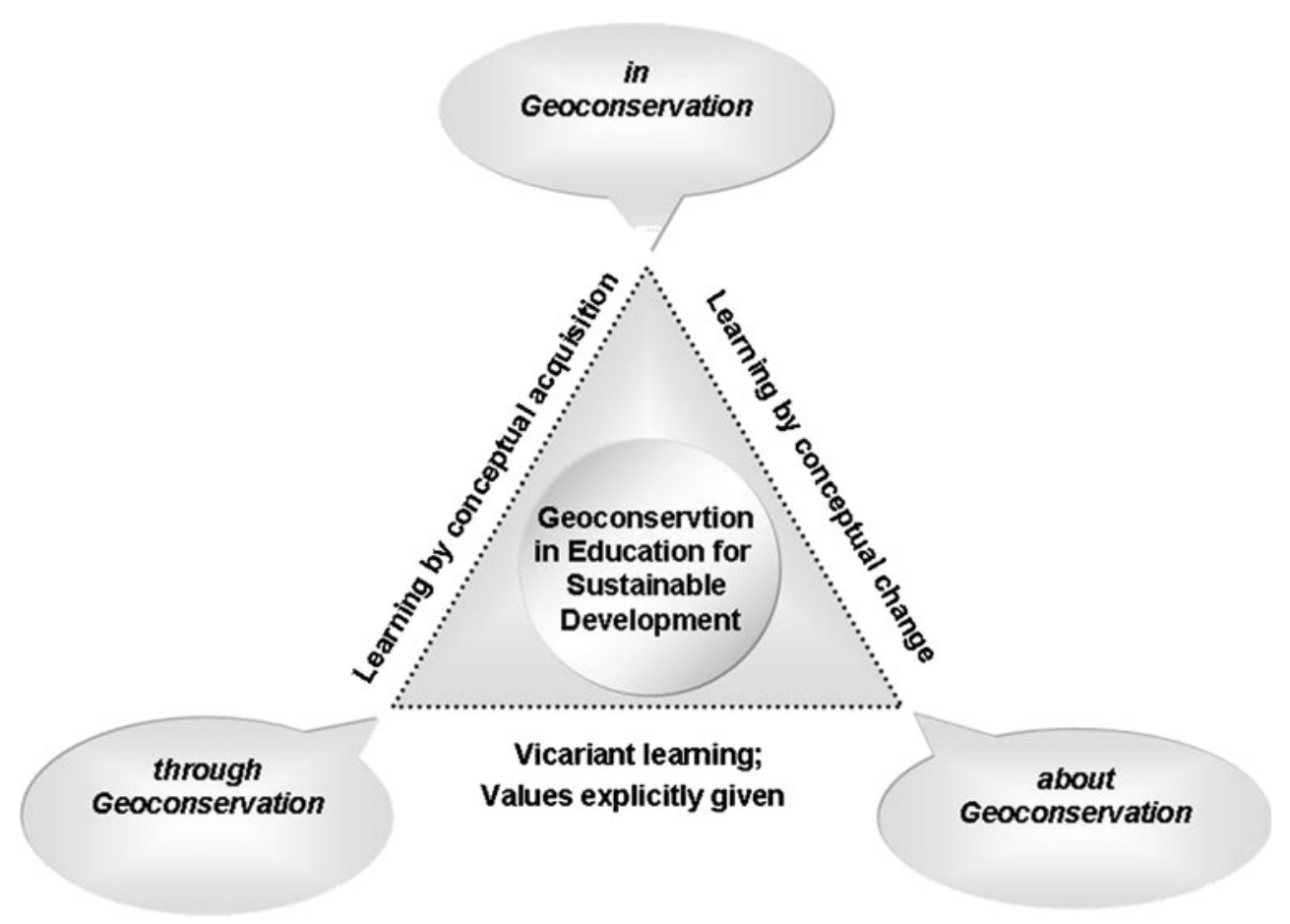


Fig. 1). Conservation and valuation purposes have been/are being developed by institutions and geoscientists through the production of technical and consultancy reports supporting formal protection of geosites and its public understanding. However, inventory and evaluation purposes, which depend on more conceptualised approaches, require further developments and consensus. They cannot be achieved without considering geoconservation as a geoscience with a clear and deep social interrelation.

Acknowledgements This work has been supported by the projects CGL2008-01273/BTE-MICIIN ("Registro Geológico de Ciclos Paleoambientales del Jurasico Medio en la Cordillera Iberica") and PTDC/ CTE-GEX/64966/2006 ("Identification, characterisation and conservation of geological heritage: a geoconservation strategy for Portugal"). The authors are deeply grateful to the reviewers, namely to W. A. P. Wimbledon, for their helpful comments on the manuscript.

\section{References}

Black G (1988) Geological conservation: a review of past problems and future promise. In: Crowther PR, Wimbledon WAP (eds) The use and conservation of palaeontological sites. Spec Pap Palaeont 40:105-111

Black GP, Gonggrijp GP (1990) Fundamental thoughts on earthscience conservation. Jb. Geol. B.-A., Band 133. Heft 4:655-657

Brilha J (2002) Geoconservation and protected areas. Environ Conserv 29(3):273-276

Brilha J (2005) Património Geológico e Geoconservação. A conservação da natureza na sua vertente geológica. Palimage, Braga

Brilha J, Wimbledon, W.A.P. ed. (2010) Geoheritage. Springer, Berlin / Heidelberg. http://www.springer.com/earth + sciences $+\% 26$ + geography/geology/journal/12371. Accessed 12 October 2010

Brilha J, Andrade C, Azerêdo A, Barriga FJAS, Cachão M, Couto H, Cunha PP, Crispim JA, Dantas P, Duarte LV, Freitas MC, Granja MH, Henriques MH, Henriques P, Lopes L, Madeira J, Matos JMX, Noronha F, Pais J, Piçarra J, Ramalho MM, Relvas JMRS, Ribeiro A, Santos A, Santos V, Terrinha P (2005) Definition of the Portuguese frameworks with international relevance as an input for the European geological heritage characterisation. Episodes 28(3):177-186

Carneiro A, Leitão V (2009) Engineers, the Geological Survey of Portugal (1857-1908), and the professionalization of geologists. In: Cardoso de Matos A, Diogo MP, Gouzevitch I, Grelon A (ed) Jogos de Identidade Profissional: Os Engenheiros entre a Formação e a Acção/ The Quest for a Professional Identity: Engineers between Training and Action, Colibri, Lisboa, pp 277-310

Carreras J, Druguet E (1998) The geological heritage of the Cap de Creus Peninsula (NE Spain): Some keys for its conservation. Geol Balc 28(3-4):43-47

Clements RG (ed.) (1984) Geological site conservation in Great Britain. Misc. Pap. Geol. Soc. 16

Crosland MP (ed) (1975) The Emergence of Science in Western Europe. Macmillan, London

Crowther PR, Wimbledon WAP (1988) The use and conservation of palaeontological sites. Spec Pap Palaeont 40:1-200

DD (1991) Digne Declaration. Declaration of the Rights of the Memory of the Earth. English translation used by ProGEO. http://www.sgu.se/hotell/progeo/digne.html. Accessed 11 October 2010
De Mulder EFJ, Nield T, Derbyshire E (2006) The International Year of Planet Earth (2007-2009): Earth Sciences for Society. Episodes 29(2):82-86

Eder W (1999) "UNESCO GEOPARKS"-A new initiative for protection and sustainable development of the Earth's heritage. N Jb Geol Palaont Abh 214(1/2):353-358

Eder W, Mulder E (2008) Paris Declaration. International Year of Planet Earth, Declaration presented at the Global Launch Event of the International Year of Planet Earth (IYPE), UNESCO, Paris, 12-13 February 2008. http://yearofplanetearth.org/index. html. Accessed 19 October 2010

Eder W, Patzak M (2004) Geoparks — geological attractions: a tool for public education, recreation and sustainable development. Episodes 27(3):162-164

EEA (2005) Sustainable use and management of natural resources. European Environment Agency, Copenhagen: 1-68. http://www. eurosfaire.prd.fr $/ 7 \mathrm{pc} / \mathrm{doc} / 1136560259$ _eea_report_9_2005.pdf. Accessed 11 October 2010

Elízaga Muñoz E (1988) Georrecursos culturales. In: Ayala-Carcedo FJ \& Pardó JF (ed) Geologia Ambiental, 1st edn., Inst. Tecnol. Geom. España, Madrid, pp 85-100

Elízaga E, Gallego E, García-Cortés A (1994) Inventaire nacional des sites d'intérêt géologique en Espagne: méthodologie et déroulement. Mém Soc Geol France ns 165:103-109

Fernández López S (1988) Biostratigrafía y Biocronología: su desarrollo histórico. In: Meléndez B (ed) Real Academia de Ciencias Exactas, Físicas y Naturales, Historia de la Ciencia, Historia de la Paleontología, pp 185-215

Fernández López S (2000) Temas de Tafonomía. Departamento de Paleontología, Univ. Complut. Madrid

Fruton JS (1988) The Liebig research group - a reappraisal. Proc Am Philos Soc 1(132):1-49

Garcia-Cortés A, Rábano I, Locutura J, Bellido F, Fernández-Gianotti J, Martín-Serrano A, Quesada C, Barnolas A, Durán JJ (2001) First Spanish contribution to the Geosites Project list of the geological frameworks established by consensus. Episodes 24(2):79-92

Geison GL (1981) Scientific change, emerging specialities, and research schools. Hist Sci 19:20-40

Geison GL (ed) (1984) Professions and the French State, 1700-1900. University of Pennsylvania Press, Philadelphia

Geison G (1993) Research schools and new directions in the historiography of science. Osíris 8 (2nd series): 227-238

Gray M (2004) Geodiversity: valuing and conserving abiotic nature. Wiley and Sons, Chichester

Gray M, Gordon J (2008) Geodiversity and the sustainable development of the regions. Eur Geol 25:28-30

Grube A (1994) The national park system in Germany. In: O'Halloran D, Green C, Harley M, Stanley M, Knill J (eds) Geological and Landscape Conservation. The Geological Society, London, pp $175-180$

Henriques MH (2004) Jurassic heritage of Portugal — state of the art and open problems. Riv Ital Paleontol Stratigr 10(1):389-392

Henriques MH (2006) O Bajociano do Cabo Mondego como recurso educativo de geociências. In: Lopes FC, Callapez PM (ed) As Ciências da Terra ao Serviço do Ensino e do Desenvolvimento: o Exemplo da Figueira da Foz, Kiwanis Clube da Figueira da Foz, pp 51-61

Henriques MH (2008) - “Ano Internacional do Planeta Terra e Educação para a Sustentabilidade". In: Vieira R et al. (ed) Ciência-TecnologiaSociedade no Ensino das Ciências-Educação Científica e Desenvolvimento Sustentável, Universidade de Aveiro, pp 110-116

Henriques MH (2010) O Ano Internacional do Planeta Terra e a Educação para a Geoconservação. In: Cotelo Neiva JM, Ribeiro A, Mendes Victor L, Noronha F, Magalhães Ramalho M (edn) Livro Branco da Geologia de Portugal. Assoc 
Portuguesa de Geólogos and Soc Geol Portugal, Lisboa, II (IV), pp 465-474

Henriques MH, Guimarães FA, SÁ AA, Silva E, Brilha J (2010) The International Year of Planet Earth in Portugal: past activities and further developments. Episodes 33(1):33-37

Holton G (1978) Fermi's group and the recapture of Italy's place in physics. In: Holton $\mathrm{G}$ (ed) The Scientific Imagination: Case Studies. Cambridge University Press, Cambridge, pp 155199

Hose TA (2008) Towards a history of geotourism: definitions, antecedents and the future. In: Burek C and Prosser CD (ed) The history of geoconservation. The Geological Society, London, Special Publication, 300: pp 37-60

Knell S (2000) The Culture of English Geology, 1815-1851. A Science Revealed through its Collecting. Ashgate, Aldershot

Kuhn T (1962) The structure of scientific revolutions. The University of Chicago Press, Chicago

Laudan R (1983) Redefinitions of a discipline: histories of geology and geological history. In: Graham L, Lepenies W, Weingart P (eds) Functions and Uses of Disciplinary Histories. Reidel, Dordrecht/Boston/Lancaster, pp 79-104

Laudan R (1990) The history of geology, 1780-1840. In: Olby RC et al (eds) Companion to the History of Modern Science. Routledge, London/New York, pp 314-325

Leenaers H, Schalke H (2004) Planet Earth in our hands. In: Nield T, Derbyshire E (eds) Earth Sciences for Society. Earth Sciences for Society Foundation, Leiden

Lima FF, Brilha JB, Salamuni E (2010) Inventorying geological heritage in large territories: a methodological proposal applied to Brazil. Geoheritage 2:91-99

Martínez-Frías J, Hochberg D (2007) Classifying science and technology: two problems with the UNESCO system. Interdiscip Sci Rev 32(4):315-319

Morrell J (1972) The chemist breeders: the research school of Liebig and Thomas Thomson. Ambix 19:1-46

Morrell JB (1990) Professionalisation. In: Olby RC et al (eds) Companion to the History of Modern Science. Routledge, London/New York, pp 980-989

Morrell JB, Thackray A (1981) Gentlemen of Science; Early Years of the British Association for the Advancement of Science. Oxford University Press, Oxford

Mulkay MJ, Gilbert GN, Woolgar S (1975) Problem areas and research networks in science. Sociology 9:187-203

O'Halloran D, Green C, Harley M, Stanley M, Knill J (eds) (1994) Geological and Landscape Conservation. The Geological Society, London

Pedrosa, MA, Moreno, MJSM (2007) Ensino Superior, Protecção Ambiental e Desenvolvimento Sustentável. In: Vasquez CV at al. (org) I Congreso Internacional de Educación Ambiental dos Países Lusófonos e Galícia, 6, Educación Ambiental e Universidade. http://www.ceida.org/CD CONGRESO lus/documentacion ea/ comunicacions/EA_e_Universidade/Pedrosa_Arminda.html Accessed 9 October 2010

Pena dos Reis R, Henriques MH (2009) Approaching an integrated qualification and evaluation system of the geological heritage Geoheritage 1: 1-10

Pereira P, Pereira D (2010) Methodological guidelines for geomorphosite assessment. Géomorphologie: relief, processus, environnement, 2: 215-222

Pereira D, Brilha J, Dias G (2008) - "Master's course on Geological Heritage and Geoconservation". Eur Geol 26:29-31

Porter R (1973) The industrial revolution and the rise of the science of geology. In: Teich M, Young R (eds) Changing Perspectives in the History of Science. Heinemann Educational Books, London, pp 320-343
ProGEO (2010) The European Association for the Conservation of the Geological Heritage. http://www.progeo.se/ Accessed 9 October 2010

Reynard E, Panizza M (2005) Geomorphosites: definition, assessment and mapping. An introduction. Géomorphologie: Relief, processus, environnement 3:177-180

Santos MEV (2004) Dos códigos de Cidadania aos códigos do Movimento CTS. Fundamentos, Desafios e Contextos. In: Martins I, Paixão F, Vieira, RM (ed) Perspectivas CiênciaTecnologia-Sociedade na Inovação da Educação em Ciência, Departamento de Didáctica e Tecnologia Educativa, Universidade de Aveiro, pp 13-22

Satkunas J, Mikulenas V, Lazauskiene J, Raudsep R, Taht K, Markots A, Lacis A (2004) Towards a geosites framework in Northern Europe - a first attempt in the Baltic States. In: Parkes MA (ed) Natural and Cultural Landscapes. The Geological Foundation, Royal Irish Academy, Dublin, pp 117-120

Servos JW (1993) Research schools and their histories. Osíris 8 (2nd series): $3-15$

Sinding-Larsen R, Hovland M, Shield D, Gleditsch N (2006) Resources issues - towards sustainable use. In: Nield T, Derbyshire E (ed) Earth Sciences for Society, Earth Sciences for Society Foundation, Leiden

Theodossiou-Drandaki I, Nakov R, Wimbledon WAP, Serjani A, Neziraj A, Hallaci H, Sijaric G, Begovic P, Sv P, Pl T, Todorov T, Zagorchev I, Antonov M, Sinnyovski D, Diakantoni A, Fassoulas Ch, Fermeli G, Galanakis D, Koutsouveli A, Livaditi A, Papadopoulou K, Paschos P, Rassiou A, Skarpelis N, Zouros N, Grigorescu D, Al A, $\mathrm{Br} \mathrm{H}$, Herlec U, Kazanci N, Saroglu F, Dogan A, Inaner H, Dimitrijevic M, Gavrilovic D, Krstic B, Mijovic D (2004) IUGS Geosites project progress - a first attempt at a common framework list for South Eastern European Countries. In: Parkes MA (ed) Natural and Cultural Landscapes. The Geological Foundation, Royal Irish Academy, Dublin, pp 81-90

Torrens H (2002) The Practice of British Geology. Ashgate, Aldershot Uceda AC (2000) Patrimonio Geológico: diagnóstico, clasificación y valoración. In: Suárez-Valgrande JP (Coord) Jornadas sobre Patrimonio Geológico y Desarrollo Sostenible, Monografías, Ministerio de Medio Ambiente, Soria, pp 23-37

UNESCO (1988) Proposed International Standard Nomenclature for Fields of Science and Technology. http://unesdoc.unesco. org/images/0008/000829/082946EB.pdf. Accessed 12 October 2010

UNESCO (2005a) UNESCO and Sustainable Development. UNESCO, http://unesdoc.unesco.org/images/0013/001393/ 139369e.pdf. Accessed 9 October 2010

UNESCO (2005b) UN Decade of Education for Sustainable Development 2005 - 2014. The DESD at a glance. UNESCO Education Sector, ED/2005/PEQ/ESD/3, http://unesdoc.unesco.org/images/ 0014/001416/141629e.pdf, Accessed 18 October 2010

UNESCO (2006) United Nations Decade of Education for Sustainable Development (2005-2014): Framework for the UNDESD International Implementation Scheme. UNESCO Education Sector, http://unesdoc.unesco.org/images/0014/001486/148650E.pdf. Accessed 9 October 2010

Van Loon AJ (2008) Geological education of the future. Earth Sci Rev $86: 247-254$

Wimbledon WAP (1988) Palaeontological site conservation in Britain: facts, form, function, and efficacy. In: Crowther PR, Wimbledon WA (ed) The use and conservation of palaeontological sites. Spec Pap Palaeont 40:41-55

Wimbledon WAP (1996) National site selection, a stop on the way to a European Geosite list. Proceedings of the Special Symposium "Geological Heritage in South-East Europe", May 1995. Geol Balcanica 26:15-27 
Wimbledon WAP (1998) An European geosite inventory: GEOSITE - an International Union of Geological Sciences initiative to conserve our geological heritage. In: Duran JJ, Vallejo M (eds) Comunicaciones de la IV Reunion Nacional del Patrimonio Geológico, Miraflores de la Sierra (Madrid). Soc Geol España, Madrid, pp 15-18

Wimbledon WAP, 1shchenko AA, Gerasimenko NP, Karis LO, Suominen V, Johansson CE, Freden C (2000a) Geosites-an IUGS initiative: science supported by conservation. In: Barettino D, Wimbledon WAP, Gallego E (eds) Geological
Heritage: Its Conservation and Management. ITGE, Madrid, pp 69-94

Wimbledon WAP, Andersen S, Cleal CJ, Cowie JW, Erikstad L, Gonggrijp GP, Johansson CE, Karis LO, Suominen V (2000b) Geological World Heritage: GEOSITES - a global comparative site inventory to enable prioritisation for conservation. In: Proceedings of the Second International Symposium on the Conservation of the Geological Heritage, Roma June 1996. Memorie Descrittive Della Carta Geologica d'Italia LVI. Servizio Geologico Nazionale: 45-60 